Article

\title{
European recovery and green jobs beyond the energy sector: wellbeing opportunity in Spanish tourism sector
}

\author{
Esther González Arnedo ${ }^{1,2^{*}}$, Antonio Sánchez-Bayón ${ }^{3 *}$, Francisco José Sastre ${ }^{4}$ \\ Universidad Rey Juan Carlos, 28033, Madrid, Spain; esther.arnedo@urjc.es \\ EAE Business School. 28002. Madrid. Spain; esther.gonzalez.arnedo@campus.eae.es \\ Universidad Rey Juan Carlos, 28033 Madrid, Spain; antonio.sbayon@urjc.es \\ ESIC Business Marketing School \& University, 28223 Pozuelo de Alarcón, Spain; franciscojose.sastre@esic.edu \\ Correspondence: esther.arnedo@urjc.es; antonio.sbayon@urjc.es
}

\begin{abstract}
This is a paper on Political Economic and Economic Policies into the European Green Deal framework and the Spanish recovery plan, with special attention to the tourism sector. First, there is a literature review, combining the scientific production with professional and institutional literature, to understand the topic development, from the former restrictive point to the current view at large. Second, it is offered a case study about the green jobs opportunity, according to wellbeing economics, for the Spanish tourism sector renewal. The paper provides valuable information to improve sectorial recovery plan, to coordinate the policymakers and the business managers and entrepreneurs.
\end{abstract}

Keywords: Political Economy; Economic Policies; European Green Deal; Recovery Plan; Green Jobs; Wellbeing Economics; Tourism \& Hospitality Sector.

\section{Introduction}

The President of the European Commission (EC), Ursula von der Leyen reaffirmed that climate change is a top priority for the European Union (EU), during the EU Green Week (June, 2021)[1]; then recalling the validity of the European Green Deal (EGD) and its extension [2-5]. The original objective of a green Europe is making this continent neutral in terms of greenhouse gas emissions by 2050 and using 32\% renewable energy by 2030 [6,7]. The EGD has insisted on the importance of moving towards European sustainability decisively, eliminating the negative impact on health of pollution, promoting responsible production and consumption, and embracing the SDGs set by UN [8]. The European strategy has placed special focus on the fast growing employment opportunities in the green economy, the so-called green jobs, which have become the most visible flagship of EGD $[9,10]$. Also, the EU is working in the improvement of EGD at large, to extend it to every economic sector, in terms of wellbeing economics: the combination of decent work with life satisfaction in better environment (3P relation: profits-planet-people). In this way, this is a great opportunity for the tourism sector, which is growing each year (of course, with the exception of the pandemic crisis and the great lockdown [11], but the forecasts sign a great and fast recovery). In a strategic view, it is a good opportunity to design the green recovery for this sector, to improve the green jobs (in terms of wellbeing) $[9,10]$.

Only jobs related to renewable energies and sustainability were initially considered green jobs: recycling, waste disposal, environmental management, environmental consulting and environmental training. According to the International Labour Organization 
(ILO) $[12,13]$, green jobs should be a source of decent work, jobs that offer equal opportunities in conditions of freedom, equity, security and dignity. International institutions and bodies, such as ILO and UNWTO (into the UN), they have carried out a wide range of studies and publications about the actual possibilities of green jobs in numerous countries and sectors within those countries, including Spain and its tourism sector [14]. Even though tourism does not quite fit into the original list of green jobs, its relevance in worldwide economy make important to study opportunities for green jobs within the tourism industry. In some international reports and studies, tourism is mentioned briefly, but the opportunities for green jobs in this important area for the Spanish economy are not developed in detail.

ILO has confirmed on numerous occasions that the green economy can create new employment opportunities worldwide. What is not so evident is whether these green jobs will be enough to compensate for the loss of other jobs in more traditional industries and sectors, and if all countries and sectors of the economy will benefit equally from the jump to the green economy and the embedded concept of decent work. Whether green jobs can be another source of employment for world tourism is a question that has yet to be fully answered. UNWTO has stated that a more sustainable tourism can provide new green employment opportunities, but studies on the possibilities of green jobs in the Spanish tourism sector have been scarce so far. Therefore, it is important to analyse the real opportunities for green jobs for the Spanish hospitality industry in order to answer a question: are green jobs a source of employment for the Spanish tourism and hospitality?

Spain is one of the most important tourist destinations in the World as well as one of the countries in Europe with the highest percentage of unemployment, so a study of possible opportunities for green jobs in the Spanish tourism sector is valuable. Tourism revenue constituted 12.4\% of Spanish GDP in 2019. In 2019, 84 million tourists arrived in Spain, which positioned this country as the most visited in Europe the year before COVID-19 pandemic crisis [15]. That same year, Spain was also designated as the most competitive country in the world in terms of tourism according to the Travel and Tourism Competitiveness Report 2019 prepared by the World Economic Forum (WEF) [16]. This report takes into account various variables when configuring its ranking. One of those variables refers precisely to the quality of human resources in the sector and the existing labour market in the country. Thus, the WEF report indicates that Spain must improve its human resource policies, so the study does not give it the highest assessment in terms of tourism competitiveness in the "human resources and people" section. The report also indicates that, despite being the most competitive country in the World in 2019, the growth of its general competitiveness index is slower than that of other neighbouring countries. This data is an important wake-up call: Spain can and must improve in many aspects of tourism and one of them is precisely the quality of its professionals and the working conditions in tourism industry. It is a matter of time before Spain can be overtaken by countries with faster growth in tourism competitiveness. This is why the study of human resources in the Spanish hospitality as well as testing the opportunities for new jobs, both decent and linked to sustainability, is a relevant area of research. If green jobs mean an opportunity for better employment at the Spanish tourism business, they are something important to study. 
The objective of this work is to analyse the perspectives and challenges that the EGD and the Recovery plan have for the Spanish tourism and more specifically for the hospitality sector, and the real opportunities for wellbeing green jobs in Spanish hotel industry. The structure of the paper is the following: 1) Theoretical framework and literature review, combining scientific production with professional and institutional materials. 2) Comparative study of the main Spanish hotel holdings and their annual CSR, to check the sustainability and employment trends by these hotels. 3) Application of qualitative tools to study the opportunities for growth of green jobs emergence among most important Spanish hotel holdings.

\section{Theoretical framework and literature review}

To economize, there is a remission to previous papers, with extended explanations on EGD, Recovery plan and green jobs [9], in the emergence of the Wellbeing Economics (WBE) [10] with digital economy and the change in business culture [17]: the new economic paradigm is based in the optimization of a triple-P-relation among profits-planet-people, supported by several international commitments [18,19]. The conections and clusters are collected in the following figure.

Figure 1a: Green jobs, wellbeing and other topics linked

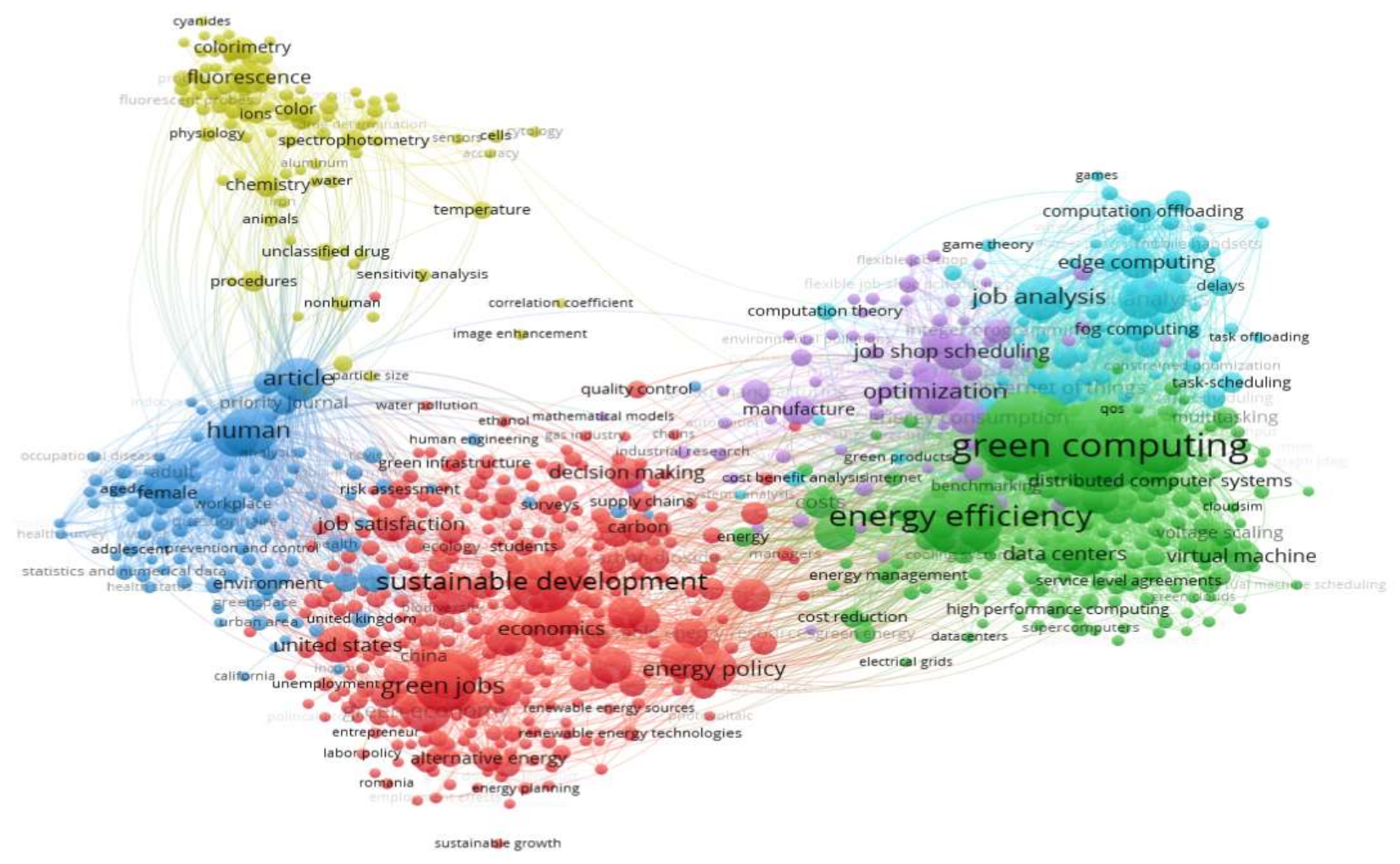

Source: own elaboration from Scopus articles (2017-21) using VOSviewer [10]. 
Figure 1b: Altmetrics in green jobs, wellbeing and other issues relaited

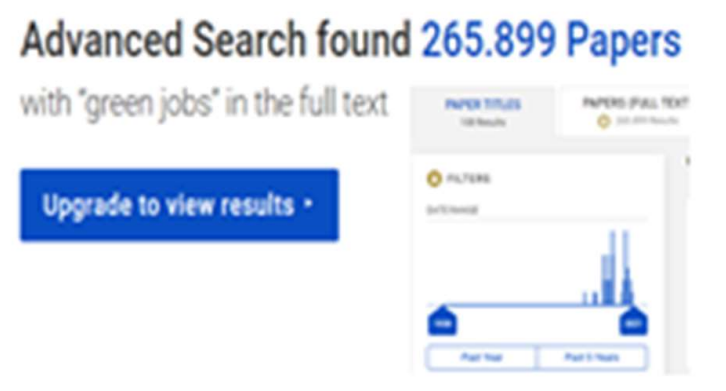

Advanced Search found 92.309 Papers with 'wellbeing economics" in the full text

Upgrade to view results *

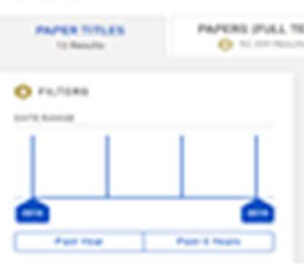

Advanced Search found 238.691 Papers

with human takent" in the full text

Upgrade to view results *

Alt-metrics Academia.edu nerms $=$

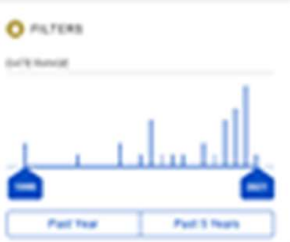

\section{Advanced Search found 565.128 Papers}

with "green recovery" in the full text

Upgrade to view results -

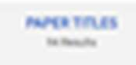

moss nas tort

o nus

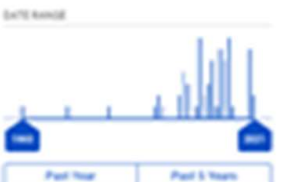

\section{Advanced Search found 546.979 Papers}

with "digital transition" in the full text

Upgrese to view results *

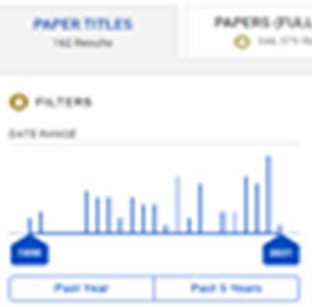

Advanced Search found 238.691 Papers

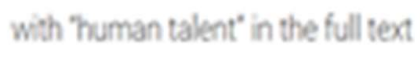

Upgrade to view results .

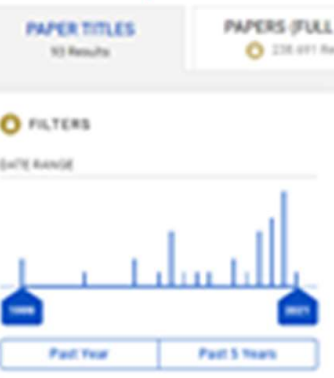

Source: own elaboration from Academia.edu publications (1960/90s-21).

In relation with the green jobs design, their skills and wellbeing stardards, as it is mentioned, the international institutions and forums have offered a reference level to establish a minimum and common scenario [14, 18-24].

\subsection{Sustainable tourism and green jobs}

Since the release of the Brundland Report [25] and its proposal for sustainable development, studies on sustainability and its implications for all sectors of the economy have grown in relevance, both in academic research and in political and economic fields. Green jobs, described as those jobs generated around the sustainability and EGD, they have become "the emblem of this sustainable economy" according to the UNEP report [26]. Studies on green economy and green tourism have increased substantially in the last decade, but it is also true that there is a lack of studies that determine what green job opportunities exist in the Spanish hotel sector under the umbrella of SDGs and sustainability policies. 


\subsection{International institutions perspective on sustainability and green jobs}

At the beginning of the green deal, the international institutions had very positive outlook regarding opportunities for decent and green jobs. As the green deal developed, some authorities and authors have started to be more cautious. After analysing statistics of green jobs in U.S. [27], Deschenes [28] concluded that the so called green jobs represented a very small share of the employment in the U.S. and its growth has been weak in the 2010 decade.

Sustainable tourism has been a popular topic in research since the 1990s, both in international institutions and scholars [29-31]. UNWTO [32] defined sustainable tourism as the one that subscribes SDGs and therefore supports the reduction of poverty, rural development, preservation of local cultures, encourages gender parity, protection of the environment and actions to mitigate climate change.

International institutions (v.g. UE, ILO, UNWTO), they have carried out studies on the impact and possibilities for tourism in the green economy[]. UNDP [33] concluded that if tourism is not properly managed, "it might have a negative impact on people, planet, prosperity and peace" (in terms of WBE). The role of tourism in sustainability is undeniable. UNWTO, UNEP and WMO report mentioned in the same conference estimated that tourism alone accounts for $5 \%$ of global emissions. In a "business-as-usual" scenario for tourism and without a sustainable approach, 30 years projections show a $150 \%$ growth emissions generated by tourism industry.

The reports of the main international organizations coincide in pointing out that green tourism can bring broad economic, social and environmental benefits, although there are also many challenges and difficulties to overcome. The UN Conference on Trade and Development [34] stated the potential of tourism to create jobs and facilitate sustainable development, especially considering that tourism is the main source of income for a third of the least developed economies on the planet [35]. It concluded that sustainable tourism is not a special type of tourism, but that all tourism must struggle to be more sustainable.

Since 2010, UNWTO ha also stated the importance of sustainability in tourism and its positive impact on decent work. UNWTO 2030 Sustainable Development Goals Agenda mentions "the need to implement policies to promote sustainable tourism that creates jobs and supports local cultures and products"[36] According to UNWTO [37], sustainable tourism must meet the triple objective of making optimal use of environmental resources; respect the authenticity of local communities, and ensure the long-term viability of its operations, providing economic benefit and employment opportunities in the communities where it operates and alleviating poverty. These three concepts: providing job opportunities, eliminating poverty and creating decent jobs are aspects clearly associated to sustainable tourism and enable a wider scope of the possibilities of work linked to sustainability.

Following the previous statement, UNWTO [38] clearly connects sustainable tourism with decent jobs. The organization concluded that tourism has a very important impact on the World economy and job creation, especially for women, youths and immigrants. Additionally, its impact on rural and indigenous communities and their connec- 
tions with other sectors of the economy is high. Sustainable tourism can and should reduce poverty and create decent jobs. This is especially relevant in tourism, traditionally characterized by monotonous and very demanding job, with high working hours, shifts and unattractive salaries.

One of the concepts that have generated more discussion in the literature has been precisely the exact definition of green job. The joint UNEP / ILO / IOE / ITUC report [39] defines a green job as any decent job that contributes to preserve and restore the quality of the environment, whether it be in agriculture, industry, services or administration, and it does so by reducing the consumption of energy and raw materials, minimizing pollution and waste, protecting and restoring ecosystems and allowing companies and communities to adapt to climate change [40]. They conclude that green jobs are any employed or self-employed job that clearly contributes to a more sustainable World.

Green jobs are often associated to the concept of decent work. The ILO (2013) concludes that both concepts should be worked together due to their link to the SDGs [41]. Regarding exact definition of green jobs, ILO reports cite the most widely accepted definitinion. ILO started the Green Jobs Global Program in 2009 [42]. Jobs are considered green when they help reduce negative environmental impacts and help create socially, economically and environmentally sustainable businesses. Green jobs are all those jobs that contribute to create a more sustainable World (remember the ILO update on the topic, connecting green jobs with other fields, like WBE, supporting the research of many scientists and scholars, see Figure 1a \& b).

Following UNWTO [43], One of the main difficulties that studies on the impact of sustainability and green jobs on tourism must face is the absence of common lists of jobs for the green sector in most countries. This makes very difficult to measure quality and quantity of green employment in tourism and actual number of green jobs in the industry. There are not common job classifications to allow researchers to find green jobs in tourism. The conceptual framework of the green economy is suggested as the basis for measuring sustainable tourism as can be seen in figure $2 \mathrm{a} \& \mathrm{~b}$.

Figure 2a: Theoretical framework of green economy

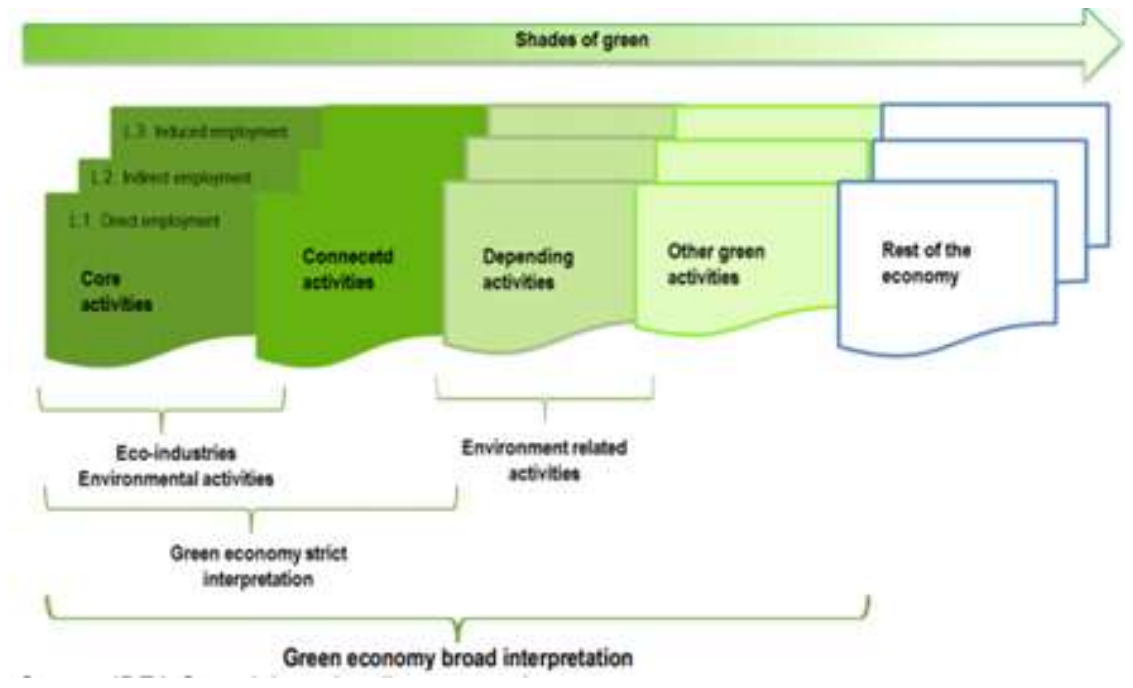

Source: UNWTO \& IDEA Consultant $[43,44]$. 
Figure 2b: Characteristics of different types of green jobs

\begin{tabular}{|c|c|c|}
\hline Type & $\begin{array}{l}\text { Purpose of } \\
\text { protecting the } \\
\text { environment }\end{array}$ & Examples \\
\hline $\begin{array}{l}\text { Core } \\
\text { activities }\end{array}$ & Primary purpose & $\begin{array}{l}\text { Environnemental protection: air pollution control, } \\
\text { protection of biodiversity, waste management } \\
\text { Resource management: water management, renewable } \\
\text { energy, recycling }\end{array}$ \\
\hline $\begin{array}{l}\text { Connected } \\
\text { activities }\end{array}$ & Secondary purpose & $\begin{array}{l}\text { Hybrid cars, green building, green ICT, organic } \\
\text { farming, sustainable tourism, sustainable forestry }\end{array}$ \\
\hline $\begin{array}{l}\text { Dependent } \\
\text { Activities }\end{array}$ & $\begin{array}{l}\text { No environmental } \\
\text { purpose but } \\
\text { dependent on } \\
\text { environmental quality }\end{array}$ & Agriculture, commercial forestry, lourism \\
\hline $\begin{array}{l}\text { Other green } \\
\text { activities }\end{array}$ & $\begin{array}{l}\text { No environmental } \\
\text { purpose }\end{array}$ & Public transport services, ICT \\
\hline
\end{tabular}

Source: UNWTO \& IDEA Consultant $[43,44]$.

The primary activities are the most directly linked to sustainability (ecological, agricultural and environmental activities) and sustainable tourism would be included in the group of secondary connected activities or in the third level "dependent activities"( described as other non-sustainable tourist activities). The UNWTO report recognizes the difficulty of correctly discriminating the activities related to green tourism, given that the general data available in reports and censuses do not usually differentiate green jobs. Only a small group of countries have established metrics for green jobs in all sectors [45]. Conversely, in most of countries the only jobs considered within the category of green jobs are those included in the basic list of positions and linked to recycling, waste management environmental management and renewable energy.

By the same token, all job categories included in the first ILO list for green jobs are jobs in traditional sectors of the green economy, i.e. environmental conservation, recycling and renewable energy jobs, eco agriculture and farming, as well as environmental training and consulting. That green job list does not connect with a significant number of people at tourism companies. Beyond the teams and professionals who work in large tourism companies on EMS and related issues: consulting, training, recycling and environmental certificates and audits the figures for green jobs in tourism are limited.

A primary source of research is precisely the categorization of green jobs within the tourism business. Ladkin and Szivas [46] mention the difficulty of determining what is and what is not a green job. As an example of the large gray area around the concept of green job, a study carried out by the government of Spain [47] asserts that the number of green jobs in Spain was 530,947 workers, equivalent to $2.6 \%$ of the Spanish workforce in 2009. The same report remarks that the total number of jobs in the green economy had doubled in a decade in Spain, becoming the average for the EU.

Nevertheless, the actual possibilities of an increase of green jobs in Spanish tourism companies are not easily identifiable. Based on these same data from Spain, the organization Green Jobs and Sustainable Development International Center (2013) -also known as GJASD International- ends up concluding that, since tourism is so important in the Spanish economy, it is reasonable to think that a part of green jobs have probably been absorbed by the tourism industry [48], but this statement is only a deduction based on general data provided in a report by the Spanish Ministry of the Environment [49] and not 
cross checked with other sources of data on green jobs in the Spanish tourism sector or any other further analysis.

Regarding to the actual work opportunities for green jobs, when we review the different document and employment estimates provided by EU about employment growth linked to sustainability, the first conclusion is that figures and forecast are very volatile throughout the years. In the case of the EU, the first statements (1997), related on sustainability and antecedent of EGD, it declared that the green economy could create between 950,000 and 1,650,000 green jobs around green energies and sustainability. This very enthusiastic initial estimate has given way to more conservative data over the years. For example, in 2021, the EU estimated that renewable energies could create between 200,000 and 300,000 jobs by 2030 , a much lower figure and which is only $12 \%$ from the previous data provided by EU authorities.

A report by Szako [50] concluded that there are possibilities for significant growth in job opportunities in the green economy, and as much as 87 million jobs susceptible of been "greeneable". This not necessarily means the creation of new jobs, but the adaptation that many current jobs, mostly in the energy sector, will experience in their way towards a greener economy. Bowen et al. [51] describe a taxonomy with the changes that green jobs could bring. There will be 1) Existing jobs whose demand will increase in the green economy 2) Existing jobs that will change substantially in tasks, skills and knowledge requiring great re-skilling 3) Emerging new jobs brought up by the demand of the green economy 4) Rival non-green jobs similar to green jobs in different sector and 5) non-green jobs not very likely to be substantially affected by the green economy. The authors don't mention green jobs for tourism, but they assert that there is potential growth of green jobs in tourism linked to the investments in sustainable tourism. Following the mentioned taxonomy tourism seems to fit better in the fifth group, that is, non-green jobs not very likely to be affected by the green economy.

ILO [52] report on opportunities for green jobs mentions Spanish tourism as one of the "areas of opportunities" for the growth of green jobs, given the importance that tourism has for the Spanish economy and the initial impulse of Spanish government towards renewable energies.

The structure of the Spanish labor market is complex, with many more skilled workers than the EU average, but also a higher percentage of unskilled workers than the EU average and far fewer medium skilled workers compared to the EU, which is interpreted as a difficulty at the time to successfully fill the green jobs, which mostly need medium-skilled workers [53,54].

Beyond the initial assessment on tourism and green jobs, ILO report does not make further analysis about the possibilities of green jobs in tourism and hospitality. In its report Green Skills for Green Jobs [55], ILO recommends increasing training in green skills in both job search workers and already employed workers, in the first ones to increase their job opportunities and in the second ones to maintain a high level of employability, because green skills will be important to maintain professional skills and will need to be updated. The report pauses briefly on the tourism sector to mention that people working at tourism will need more training and re-skilling in new knowledges and skills in environmental aspects, especially in topics such as ecotourism, bio tourism 
and circular tourism and energy management systems, but opportunities for green jobs are not mentioned. Tourism will need skilling and re-skilling on green topics, but not an increase in new and specific green jobs.

Regarding green jobs at the tourism sector in Spain, Sánchez and Poschen [56] in their technical note for ILO, initially estimated that only renewable energies could generate 20 million jobs throughout the EU. Several years later, the report sponsored by the Government of Spain Green Employment in a Sustainable Economy[57] concluded that the sustainable economy could allow Spain to create 1.153 .000 total green jobs. Same study estimates that green economy could create up to 24.000 new jobs in Spanish Tourism, a very humble figure, especially when compared to the total green jobs forecasted for Spain.

According to a study by the Biodiversity Foundation sponsored by the Spanish Ministry of Environment [49], one of the most important conditions for governments to decide to promote policies and actions related to sustainability largely depends on the impact of these measures on employment. According to the same study, almost 4.5 million people (full-time equivalent-FTE) in the EU worked at the green economy in 2016, 1.4 million more than fifteen years ago. However, overall employment estimates provided by the 2009 Spanish study, later mentioned by ILO, does not coincide with the recent data issued by the EU regarding green jobs. In the case of Spain, after the shift in the Spanish legislation about renewables energies in 2015, cutting back subventions to those energies, estimation for new green jobs fell down to 46,534 direct jobs and 29,121 indirect jobs in 2015, a very modest figure when compared with 2009 predictions about 530.947 green jobs.

\subsection{Academic literature on sustainable tourism and green jobs}

Sustainable tourism has had broad resonance in tourism research, being perceived as an opportunity to address new issues beyond the negative impacts of the activity, which were present in the literature in previous decades of research [58]. Buckley \{59\} estimates that more than 5000 papers on sustainable tourism have been published in the last 25 years, confirming the great interest of scholars in sustainability and its implications. Hall [31,60] considers that the relationship between tourism and the environment has become increasingly problematic as it is accepted that tourism leads to a degradation of natural resources in both the short and long term. The author asserts that tourism is essentially about renting a place in another country or another location for a given agreed time, so the risk for the environment in those rented locations can be high if it is not controlled.

Torres-Delgado \& Palomeque [61] analyze the policies and studies on sustainability carried out up to that year. His first conclusion is that the proliferation of documents in sustainable tourism has not led to a proportional advance either in theoretical or practical aspects on this concept. Sustainability in tourism research has been first associated with environmental aspects to progress later towards more holistic approaches, seeing sustainability as a tool for economic development, well being and preservation of the 
environment. The authors also concluded that research on sustainable tourism have more interest in the environment and less in social and economic aspects.

Branwell \& Lane [62] agree that research on sustainability in tourism has been important in the academic world and has become increasingly robust and varied thanks to the support of public sectors, national research councils and the private sector that they have provided. funds to support research in sustainable tourism.

Other authors are still critical of the prevailing trends in tourism research and sustainability, defined by Hall $[31,60]$ as neoliberal. After reviewing the studies on tourism and sustainability, this author laments the paucity of research on the true contribution of tourism to sustainability, all at a time when tourism seems less sustainable than ever. However, studies on green jobs are still scarce.

Regarding academic research on sustainable tourism and its impact on employment, it is important to highlight that there is no consensus among the different authors regarding the positive impact on the labor market of sustainability policies. The work of Álvarez et al [63] is skeptical with respect to the real possibilities of the green economy to create employment without destroying it in other sectors of activity.

According to the author, following the first EU announcements about employment opportunities in green jobs in 1997, many voices rose above the general euphoria to point out that sustainability policies might create jobs in the green economy, especially renewable energies, but it will also destroy jobs in other sectors, due to the loss of competitiveness in other businesses due to the higher cost of renewable energies and the transfer of funds to that green energies in detriment of other areas of the country economy. Thus, each megawatt obtained through renewable sources destroys an average of 5.05 jobs, given the high cost of generating that green energy and the risk of company's closures and relocations. In other words, the jobs created by sustainable energies are created by destroying jobs in other sectors. A study by Sulich and Rutkowska [64], on green job opportunities for young people in three European countries (Poland, Belgium and the Czech Republic) concluded that more than 15\% of new youth jobs in Poland and Belgium were green jobs. However, the proportion was much lower in the Czech Republic where only $2 \%$ of job offers for young people came from the green economy. Opportunities in the green economy are unequal depending on each country, its productive sectors and the available workforce.

Research on sustainability in tourism enjoys a boom in recent years and the increase in articles and papers has grown dramatically. Niñerola et al. [65] confirm that the number of publications on the subject has reached 4,647 publications. There is a growing interest both in sustainability in tourism and in all related concepts: circular tourism, blue tourism, blue tourism, bio tourism and ecological tourism. However, few studies have focused on the impact of measures related to sustainability on human resources and the impact of employment in tourism industries.

A good share of studies focuses on the different concepts of sustainable tourism and their implications. Ruhanen et al. [66] confirm that sustainability is a topic of extraordinary interest. However, the specific topic of decent work and sustainability in the tourism sector is still low in studies [67]. Bianchi and DeMan [68] point out that the vision of legislators and governments on tourism work is in many cases superficial, 
concentrating above all on the possibilities of a constantly growing sector and less on aspects of justice and work equity at tourism companies.

Regarding sustainability in the Spanish hotel sector, Ayuso [69] indicates that the tourism sector is less regulated in Spain than other sectors, which has led tourism and hotel companies to establish voluntary sustainability instruments, as they are more flexible, innovative and easy to implement. The voluntary practices that are mentioned as more frequent at tourism companies are mainly codes of conduct, implementation of best practices, eco-labels, environmental management systems and environmental performance indicators. Many small hotels have embraced a wide range of ecolabels to show their commitment with the environment and create a competitive advantage, but also big hotel chains use a combination of all available tools, from EMS to ecolabels. In large Spanish hotel chains, sustainability and CSR reports include sections dedicated to their people, with numerous measures that fit into the category of decent work (and beyond, with motivational actions and CSR 3.0 [70]). Although there are not mentions about green jobs, main Spanish hotel chains are implementing a wide list of initiatives for decent work as described by ILO as we will explain later.

Rodríguez-Antón et al. [71] analyzed the sustainability tools of Spanish hotels, confirming the interest of this sector in establishing voluntary sustainability tools that coincide with those mentioned in the previous Ayuso's study: eco-labels, implementation of good environmental practices and certifications. Rubio [72] confirms that the Spanish hoteliers are involved in different actions related to sustainability, with a vast majority of companies having an interest in the positive impact of environmental policies and practices on the hotel's corporate reputation and its brand image. The authors also highlight that there is much more interest in eco-labels and only the large hotel chains opt for more sophisticated environmental management systems (EMS) integrated in ISO norms or similar standards.

Coles et al. [73] point out that studies on sustainability on many occasions ignore the implications for workers in the tourism sector themselves and are surprised by the low interest of employment offered in tourism in relation to quality jobs. Baum et al. [74] declare that many tourism companies have changed their human resource strategies to be aligned with their corporate social responsibility in order to improve their recruitment and training practices, and the working conditions of their employees, Same authors indicate that research on sustainable tourism on many occasions ignores aspects related to workers in the tourism sector and conclude that the most popular lines of research have not studied enough the implications of sustainability on the workforce and the possibilities of decent work associated with green jobs, important topic in a sector characterized by temporary and precarious conditions. Other authors remark the importance of sustainable practices linked to the right people's management. Winchenbach et al. [75] point out that poor working conditions in tourism create feelings of mistrust that negatively affect both workers and the business itself when sustainability measures are launched without taking into account other HR aspects.

Thus, another line of research in Spanish hospitality, addresses the growing importance of GHRM (Green Human Resources Management) in Spanish hotels. Úbeda-García et al. [76] mention the increasing relevance of all CSR and green practices 
for Human Resources Management at Spanish hotels. GHRM is linking its main activities to a green management of people with green recruitment, training and employee's management. When GHRM is put in place, employee's satisfaction increase and happier employees are associated in literature with better company's perfomance.

Sustainability policies and practices are an important tool to attract new generations to hospitality. The tourism industry has traditionally had great difficulty in attracting and retaining good professionals. The jobs offered are in many cases monotonous, with long working hours, shifts and unattractive salaries [77-79]. Hospitality is less attractive for the new generations joining the job market. That is why tourism companies worldwide, and especially hotel companies, have made a great effort to increase their attractiveness as employers, shifting from being invisible in the year 2000 to hit top positions in most prestigious lists. Hilton hotels were ranked among the best places to work at on the Fortune 2020 list [80], and many other hotel chains as Marriot or Kimpton also ranking high.

Another aspect to consider is the positive impact of green strategies and green credentials on the image of hotels in order to attract and retain best. Hospitality is interested to attract best candidates and the right sustainability and CSR can create the competitive advantage. Goh et al. [81], their study confirms the interest of the new generations in working in companies that are committed to sustainability. New generations value very positively all aspects of CSR in their potential employers. Tourism companies must compete for the best professionals [82]. Green practices increase employee satisfaction and productivity [83,84]. A green company is more attractive and generates higher levels of satisfaction and commitment in its employees and this is fundamental for the hotel sector (in the way of WBE [10]).

\section{Study case: Green jobs and wellbeing opportunity in Spanish hospitality}

Spain had in 2019, right before the COVID-19 crisis, nearly 16,000 hotels with more than $3,500,000$ rooms, with $11 \%$ of the total hotel supply in Europe, so its importance within the Spanish tourism sector and its contribution to Spanish GDP ranges between $1.5 \%$ and $1,7 \%$. Spanish hotels employs more than 200,000 people [85].

Until the 90s, the hotel sector was not very active in sustainability and environment issues, but as of the 2000s, the annual reports of the main companies began to steadily dedicate more time and resources to green topics.

According to their yearly turnover, the top Spanish hotel chains in 2019 were those detailed in Table 2:

Tabla 2: Top Spanish hotels by turnover

\begin{tabular}{|l|l|}
\hline Hotel & $\begin{array}{l}2019 \text { turnover } \\
\text { (Millions of Euros) }\end{array}$ \\
\hline Meliá Hotels & 2.846 \\
\hline Iberostar Hotels and Resorts & 2.353 \\
\hline RIU Hotels & 2.240 \\
\hline Barceló & $2.218,4$ \\
\hline
\end{tabular}




\begin{tabular}{|l|l|}
\hline NH Hotel Group & $1.178,3$ \\
\hline Bahía Principe Hotels \& Resorts & 800 \\
\hline Palladium & 752 \\
\hline H10 Hotels & 660 \\
\hline Eurostars Hotel Company & 620 \\
\hline Princess Hotels & 286,8 \\
\hline
\end{tabular}

Source: own elaboration based on Hosteltur 2019 data [86].

Our study has two phases, in the first we analyze the CSR annual reports to detect more outstanding aspects in relation to sustainability and green jobs. In the second part we have interviewed two managers of human resources and / or quality and environment certifications in the sector to obtain expert opinions and confirm if there are prospects for an increase in hiring related to green jobs and what other measures hotel chains are implementing in this fields. The interviewed experts work within the ITH (Instituto Tecnológico Hotelero)[87] a non-profit organization that supports innovation and technology initiatives within the Spanish hotel sector.

For the purposes of this study, we have selected the top five hotel chains (Meliá, Iberostar, RIU, Barceló and NH), given that their business volume and number of employees can allow a fairly accurate view of the degree to which the Spanish hotel sector is committed to the environment and analyze whether there are mentions of green jobs in its corporate reports, meaning green jobs are decent jobs and are committed to sustainability. We have chosen these companies because the quality and detail of the reports makes data analysis much easier.

The Spanish hotel holdings studied, they have international presence, with hotels in numerous world destinations and they publish very complete sustainability and CSR reports, with additional information on their human capital and the actions taken to guarantee decent work environments (many of them, they are part of Global Compact-UN, Wellbeing Economy Alliance-WEF, etc.). For the purposes of this study, we will review whether the companies' latest CSR reports. Those reports are public and easily accessible on corporate webpages.

Aspects to be analyzed:

- Adherence to the SDGs and how it is being applied in a concrete way in the hotel chain

- Good sustainability practices (recycling and energy saving)

- EMS or Environmental certifications (ISO 14,000 and ISO 15,000)

- Human resource practices linked to decent work: non-discrimination, equality, justice and fair wages

- Mention to green jobs in corporate documentation

Tabla 3: Top Spanish hotels leading the transition

\begin{tabular}{|l|l|l|l|l|l|l|}
\hline Hotel & $\begin{array}{l}\text { Total } \\
\text { hotels }\end{array}$ & $\begin{array}{l}\text { Adhesion to } \\
\text { SDG }\end{array}$ & $\begin{array}{l}\text { Sustainable } \\
\text { practices }\end{array}$ & EMS & Decent jobs & $\begin{array}{l}\text { Mention/visibility } \\
\text { of green jobs }\end{array}$ \\
\hline Meliá & 367 & YES & YES & YES & YES & NO \\
\hline
\end{tabular}




\begin{tabular}{|l|l|l|l|l|l|l|}
\hline Hoteles & & & & & & \\
\hline Iberostar & 118 & YES & YES & YES & YES & NO \\
\hline RIU & 92 & YES & YES & YES & YES & NO \\
\hline Barceló & 265 & YES & YES & YES & YES & NO \\
\hline NH Hotels & 361 & YES & YES & YES & YES & NO \\
\hline
\end{tabular}

Source: own elaboration based on Hosteltur 2019 data [86].

All the hotels analyzed mention numerous sustainable practices in the areas of recycling, waste management and energy saving. All the companies have implemented EMS, most of them with ISO 14.000 certificates. Their reports, published in 2020, reflect an interest in keeping human teams motivated and engaged during the pandemic through numerous communication and training actions (in the way of WBE). Additionally, all of them mention varied collaborations with numerous NGOs and charitable organizations. They all present aspects of fair treatment, support for diversity, benefits, work-life balance opportunities, training and equal opportunities. None mention job opportunities in green jobs. In the case of chains such as NH Hotels, they have mention appearing in the Dow Jones Sustainability Index as Best in its class.

After interviewing the experts, they confirmed that the number of possible green jobs, at least as defined by the ILO, is relatively few in large hotel chains, focusing above all on the relatively small teams in charge of environmental management within organizations. The operational jobs at the heart of the business remain traditional in the hospitality industry. The greatest impact of actions associated with core sustainability practices such as recycling and waste disposal are frequently outsourced external companies that are in charge of recycling waste from hotel establishments and other sustainability support services.

\section{Discussion and conclusions}

Although UNWTO and ILO afirm that there are good opportunities for green jobs in the tourism sector, an analysis of the Spanish hospitality confirms that green jobs are still a few in this sector (with many possibilities to increase). However, the large Spanish hotel holdings are making a great effort on key sustainability and wellbeing issues. In the first step of this strategical reconversion, the Spanish hotel holdings are putting in place environmental management systems backed in all cases analyzed by ISO 14000 certificates and a commitment to generating decent and sustainable jobs. These efforts have a triple benefit: they contribute to sustainability, increase hotel reputation for customers and candidates and increase employee's pride of belonging. More than the creation of new positions linked to green jobs in hospitality, what most likely happens in the sector is the addition of green skills in already existing job profiles, that is training in new skills and knowledges linked to the green economy. Job description of most of the professional positions in the hotel sector would increasingly include green skills and sustainability awareness, but at the moment a significant increase in green jobs within the hotel industry is not noticeable. The second step in the reconversion is started now, 
thanks to recovery plan and aligned with EGD at large. It means that there will be more attention in wellbeing terms: in the 3 P relation (profit-planet-people), it must to improve the $\mathrm{p}$ for people, with motivational actions (i.e. gamification, open projects \& teams, celebration events, win-win practices).

This transformation of the sector is neccesary, also, caused by digital transition and its impact in the business culture: under the digital economy, the hotels and their employees can't be focused just in the room services. The reconversion of the sector has to deal with the first step of digital economy: the gig economy, which includes the collaborative \& circular economy, the autonomous economy and the orange economy. The next step of the digital economy is WBE: the new green jobs (according to the Ricardo effect or readjustment), they have to attend to industry of emotions and experiences; so it is necessary to count with talent-collaborators, who keep the 3P relation in a motivational way (not as a coercive issue, better as a win-win game with higher satisfaction for everyone $[9,10,17,70])$.

A complementary study (as a future research line), it should analyze the sector of small hotels, rural and ecological hotels that have doubled in number in the last decade and that can bring out more one hundred percent green jobs and more varied and flexible environmental management models.

Author Contributions: Conceptualization, M.G.V., A.S.B.; investigation, M.G.V., A.S.B., J.L.; writing-original draft preparation, M.G.V., A.S.B.; writing-review and editing, M.G.V., A.S.B., J.L.; supervision, M.G.V., A.S.B., J.L. All authors have read and agreed to the published version of the manuscript.

Funding: Not applicable.

Institutional Review Board Statement: Not applicable.

Informed Consent Statement: Not applicable.

Data Availability Statement: Not applicable.

Acknowledgements: to GESCE-URJC, GID-TICTAC CCEESS-URJC and TRANS-REAL LAB-UVA.

Conflicts of Interest: The authors declare no conflict of interest.

\section{References}

1. European

Commission.

EU Green

Week.

Available

online: https://ec.europa.eu/environment/news/eu-green-week-2021-zero-pollution-conclusions-2021-06-04_en; retrieved June 2021.

2. European Commission. Renewable directive. Available online: https://ec.europa.eu/energy/topics/renewable-energy/renewable-energy-directive/overview_en; retrieved June 2021.

3. European Commission. The European Green Deal COM/2019/640 Final. Available online: https://eur-lex.europa.eu/legal-content/EN/TXT/?uri=COM\%3A2019\%3A640\%3AFIN (accessed on May 15, 2021).

4. European Commission. Recovery Plan for Aurope. Available online: https://ec.europa.eu/info/strategy/recovery-plan-europe_en (accessed on May 15, 2021).

5. EUR-lex (2021). Regulation (EU) 2021/241 of the European Parliament and of the Council of 12 February 2021 establishing the Recovery and Resilience Facility. Available online: https://eur-lex.europa.eu/legal-content/EN/TXT/?uri=CELEX\%3A32021R0241 (accessed on May 15, 2021).

6. Vindel, J.M.; Trincado, E.; Sánchez-Bayón, A. European Union Green Deal and the Opportunity Cost of Wastewater Treatment Projects. Energies 2021, 14, 1994. https://doi.org/10.3390/en14071994

7. Heredia Yzquierdo, J.; Sánchez-Bayón, A. The European transition to a green energy production model. Italian feed-in tariffs scheme \& Trentino Alto Adige mini wind farms case study. Small Bus. Int. Rev. 2020, 4, 39-52, doi:10.26784/sbir.v4i2.246.

8. Trincado, E.; Sánchez-Bayón, A.; Vindel, J.M. The European Union Green Deal: Clean Energy Wellbeing Opportunities and the Risk of the Jevons Paradox. Energies 2021, 14, 4148. https://doi.org/10.3390/en14144148

9. García Vaquero, M.; Sánchez-Bayón, A.; Lominchar, J. European Green Deal and Recovery Plan: Green Jobs, Skills and Wellbeing Economics in Spain. Energies 2021, 14, 4145. https://doi.org/10.3390/en14144145 
10. Sánchez-Bayón, A., García-Vaquero, M., Lominchar, J. Wellbeing Economics: beyond the Labour compliance \& challenge for business culture. J. Leg. Ethical Regul. Issues 2021, 24 (special isssue), 1-15.

11. Bagus, P.; Peña-Ramos, J.A.; Sánchez-Bayón, A. COVID-19 and the Political Economy of Mass Hysteria. Int. J. Environ. Res. Public Health 2021, 18, 1376. https://doi.org/10.3390/ijerph18041376

12. International Labour Organization (ILO). Guidelines for a just transition towards environmentally sustainable economies and societies for all. Available online: https:/www.ilo.org/global/topics/green-jobs/publications/WCMS 432859/lang--en/index.htm (accessed on May 15, 2021).

13. International Labour Organization (ILO) Green jobs skills. Available online: https://www.ilo.org/wcmsp5/groups/public/---ed_emp/---ifp skills/documents/publication/wcms 709121.pdf; retrieved June 2021

14. CEDEFOP (2018). Skills for green jobs in Spain: an update. Available online: http://www.cedefop.europa.eu/files/spain_green_jobs_2018.pdf; retrieved May 2021.

15. European Commission. Eurostat statistics explained. Available online: https://ec.europa.eu/eurostat/statistics-explained/index.php?title=Tourism statistics; retrieved May 2021

16. Weforum (2019). The travel tourism competitiveness report. Available online: https://es.weforum.org/reports/the-travel-tourism-competitiveness-report-2019; retrieved May 2021

17. Sánchez-Bayón, A., Trincado, E. Business and labour culture changes in digital paradigm. Cogito 2020, 12(2), 225-243.

18. OECD. The economy of Well-Being. Available online: The Economy of Well-Being - OECD (accessed on May 15, 2021).

19. WEF. Wellbeing Economy Alliance. Available online: About - Wellbeing Economy Alliance (accessed on May 15, 2021).

20. IEA and International Monetary Fund. Sustainable Recovery: World Energy Outlook. Available online: Sustainable Recovery - Analysis - IEA (accessed on May 15, 2021).

21. Skills-OVATE. Skills Online Vacancy Analysis Tool for Europe. Available online: https://www.cedefop.europa.eu/en/data-visualisations/skills-online-vacancies/skills/occupations (accessed on May 15, 2021).

$\begin{array}{llcccc}\text { 22. } & \text { OECD (2018). Skills } & \text { statistics } & \text { by } & \text { country } & \text { Stat. } \\ \text { https://stats.oecd.org/Index.aspx?DataSetCode=SKILLS } & 2018 \text { TOTAL\# (accessed on May 15, 2021). }\end{array}$

23. CEDEFOP. Skills for green jobs in Europe. Available online: Skills for green jobs: 2018 update I Cedefop (europa.eu) (accessed on May 15, 2021).

24. O*NET online. Available online: https://www.onetonline.org (accessed on May 15, 2021).

25. Brundtland, G. H., Khalid, M., Agnelli, S., Al-Athel, S., \& Chidzero, B. J. Our common future. World Commission on Environment and Development, New York, NY, 1987.

26. VV.AA. (2007). PNUMA Annual Report. Available online: Informe anual del PNUMA de 2007 (unep.org); retrieved May 2021.

27. US Bureau of Labor Statistics. Measuring Green Jobs. Available online: https://www.bls.gov/green/home.htm https://www.bls.gov/green/home.htm (accessed on May 15, 2021).

28. Deschenes, O. Green jobs (No. 62). IZA Institute of Labor Economics: Bonn, Germany, 2013.

29. Niñerola, A., Sánchez-Rebull, M. V., \& Hernández-Lara, A. B. Tourism research on sustainability: A bibliometric analysis. Sustainability 2019, 11(5), 1377.

30. Ruhanen, L., Weiler, B., Moyle, B. D., \& McLennan, C. L. J. Trends and patterns in sustainable tourism research: A 25-year bibliometric analysis. Journal of Sustainable Tourism 2015, 23(4), 517-535.

31. Hall, C.M. Constructing sustainable tourism development: The 2030 agenda and the managerial ecology of sustainable tourism. Journal of Sustainable Tourism 2019, 27(7), 1044-1060.

32. UNWTO. Sustainable Development of Tourism, 2012. Available online: http://sdt.unwto.org/en/content/about-us-5; retrieved May 2021.

33. VV.AA. UNDP Annual Report 2017. Available online: https://annualreport.undp.org/2017/; retrieved May 2021.

34. VV.AA. UNWTO Sustainable Development of Tourism, 2012. Available online: http://sdt.unwto.org/en/content/about-us-5; retrieved May 2021.

35. VV.AA. Making Tourism more Sustainable. A Guide for Policy Makers. United Nations Environment Programme and World Tourism Organization, Madrid, Spain, 2015.

36. VV.AA. UN Sustainable development goals. Available online: https://www.un.org/sustainabledevelopment/sustainable-development-goals/; retrieved June 2021.

37. VV.AA. The Contribution of Tourism to Trade and Development. Note by the UNCTAD secretariat. TD/B/C.I/8, 2010.

38. VV.AA. $6^{\text {th }}$. International Conference in Tourism statistics measuring for sustainable tourism. Available online: https://www.unwto.org/archive/asia/event/6th-international-conference-tourism-statistics-measuring-sustainable-tourism; retrieved May 2021.

39. ILO. Sustainable development, decent work and green jobs. Report V. International Labour Conference. 102 nd Session, 2013. Geneva 2013. Available online: http://www.ilo.org/wcmsp5/groups/public/@ed norm/@relconf/documents/meetingdocument/wcms 207370.pdf; retrieved: June 2021.

40. VV.AA. Green Jobs Programme of the ILO. Available online: http://www.ilo.org/wcmsp5/groups/public/---ed emp/---emp_ent/documents/publication/wcms_371396.pdf; retrieved May 2021. 
41. Poschen, P. Decent work, green jobs and the sustainable economy: Solutions for climate change and sustainable development. Routledge, London, UK, 2017.

ILO

green jobs.

Available

online: https://www.ilo.org/global/topics/green-jobs/WCMS_213842/lang--en/index.htm; retrieved May 2021.

43. Chernyshev, I. Employment, Green Jobs and Sustainable Tourism. Available online: http://webunwto.s3.amazonaws.com/imported_images/48535/chernyshev_conf2017manila_central_paper.pdf; retrieved May 2021.

44. Bilsen, V., et al. Green jobs. Final report. IDEA Consult in collaboration with RDC Environment (3E). Brussels, May 2010. Available online: file:///D:/downloads/Final\%20report\%20green\%20jobs\%20IDEA.pd; retrieved May 2021.

45. Ruhanen, L; Weiler, B; Moyle, Brent D; et.al. Trends and patterns in sustainable tourism research: a 25-year bibliometric analysis. Available

online: https://research.usc.edu.au/discovery/delivery/61USC INST:ResearchRepository/12126531810002621?1\#13126954280002621; retrieved April 2021.

46. Ladkin, A., \& Szivas, E. Green jobs and employment in tourism. Tourism in the Green Economy. Routledge, London, UK, 2015.

47. Spanish Ministry of Enveronment. Empleo verde en una economía sostenible. Available online: http://www.upv.es/contenidos/CAMUNISO/info/U0637188.pdf; retrieved June 2021.

48. VV.AA. Green jobs for sustainable tourism. Available online: https://webunwto.s3-eu-west-1.amazonaws.com/imported_images/45423/gjasd_international.pdf Retrieved, May 2021.

49. European Commission: Renewable energy in Europe, 2020. Available online: https://ec.europa.eu/info/news/focus-renewable-energy-europe-2020-mar-18 en; retrieved May 2021.

50. Czako, V. Employment in the Energy Sector. Publications Office of the European Union, Luxembourg, 2020. doi:10.2760/95180.

51. Bowen, A., Kuralbayeva, K., \& Tipoe, E. L. Characterising green employment: The impacts of 'greening' on workforce composition. Energy Economics 2018, 72, 263-275.

52. ILO (2012) Green Jobs for sustainable development, a case study for Spain. Available online: https://www.ilo.org/wcmsp5/groups/public/---ed emp/--emp ent/documents/publication/wcms 186715.pdf; retrieved May 2021.

53. European Commission. Eures: Short overview of the labour market. Available online: https:/ec.europa.eu/eures/main.jsp?catId=2627\&countryId=ES\&acro=lmi\&lang=en retrieved May 2021

54. European Commission. Labour markets. Available online: https://ec.europa.eu/eurostat/documents/3217494/5734929/KS-HA-12-001-05-EN.PDF.pdf/f60b7339-a767-4400-8036-1d6294913 a23?t=1414776599000; retrieved May 2021.

55. ILO (2011) Green fkills Green Jobs. Available online: https://www.ilo.org/global/publications/ilo-bookstore/order-online/books/WCMS 159585/lang--en/index.htm; retrieved May 2021.

56. Sanchez, A.B., \& Poschen, P. (2010). The social and Decent Work dimensions of a new Agreement on Climate Change. Available online: https://www.uncclearn.org/wp-content/uploads/library/ilo22.pdf; retrieved May 2021.

57. Spanish Government. Informe sobre empleo verde. Available online: https://www.empleaverde.es/sites/default/files/informe_empleo_verde.pdf; retrieved May 2021.

58. Bramwell, B., \& Lane, B. Towards innovation in sustainable tourism research? Journal of Sustainable Tourism 2012, 20(1), 1-7

59. Buckley, R. Sustainable tourism: Research and reality. Annals of tourism research 2012, 39(2), 528-546.

60. Hall, C.M. Economic greenwash: On the absurdity of tourism and green growth. In Tourism in the green economy. Routledge, London, UK, 2012.

61. Torres-Delgado, A., \& Palomeque, F. L. The growth and spread of the concept of sustainable tourism: The contribution of institutional initiatives to tourism policy. Tourism Management Perspectives 2012, 4, 1-10.

62. Bramwell, B., Lane, B. What drives research on sustainable tourism? Journal of Sustainable Tourism 2015, 23(1): 1-3.

63. Álvarez, G.C., Jara, R.M., Julián, J.R.R., Bielsa, J.I.G. Study of the effects on employement of public aid to renewable energy sources. Procesos de mercado: revista europea de economía política 2010, 7(1), 13-70.

64. Sulich, A., \& Rutkowska, M. Green jobs, definitional issues, and the employment of young people: An analysis of three European Union countries. Journal of environmental management 2020, 262, 110314.

65. Niñerola, A., Sánchez-Rebull, M.V., Hernández-Lara, A.B. Tourism research on sustainability: A bibliometric analysis. Sustainability 2019, 11(5), 1377.

66. Ruhanen, L., Weiler, B., Moyle, B.D., McLennan, C.L.J. Trends and patterns in sustainable tourism research: A 25-year bibliometric analysis. Journal of Sustainable Tourism 2015, 23(4), 517-535.

67. Ioannides, D., Gyimóthy, S., James, L. From liminal labor to decent work: A human-centered perspective on sustainable tourism employment. Sustainability 2021, 13(2), 851.

68. Bianchi, R.V., de Man, F. Tourism Inclusive growth and decent work: A political economy critique. J. Sustain. Tour 2020. 28, 119.

69. Ayuso, S. Adoption of voluntary environmental tools for sustainable tourism: Analysing the experience of Spanish hotels. Corporate social responsibility and environmental management 2006, 13(4), 207-220. 
70. Sánchez-Bayón, A., García-Ramos, M.A. A win-win case of CSR 3.0 for wellbeing economics: digital currencies as a tool to improve the personnel income, the environmental respect \& the general wellness. REVESCO 2021, 138: 1-11. DOI: https://doi.org/10.5209/reve.75564

71. Rodríguez-Antón, J.M., del Mar Alonso-Almeida, M., Celemín, M. S., Rubio, L. Use of different sustainability management systems in the hospitality industry. The case of Spanish hotels. Journal of Cleaner Production 2012, 22(1), 76-84.

72. Rubio, M.V. La sostenibilidad ambiental del sector hotelero español. Una contribución al turismo sostenible entre el interés empresarial y el compromiso ambiental. Arbor 2017, 193(785), 403.

73. Coles, T.; Fenclova, E.; Dinan, C. Tourism and corporate social responsibility: A critical review and research agenda. Tour. Manag.Perspect 2013. 6, 122-141.

74. Baum, T.; Kralj, A.; Robinson, R.N.; Solnet, D.J. Tourism workforce research: A review, taxonomy and agenda. Ann. Tourism. Research, 2016, 60: 1-22. DOI: 10.1016/j.annals.2016.04.003

75. Winchenbach, A.; Hanna, P.; Miller, G. Rethinking decent work: The value of dignity in tourism employment. J. Sustainable Tourism 2019, 27, 1026-1043.

76. Úbeda-García, M., Claver-Cortés, E., Marco-Lajara, B., \& Zaragoza-Sáez, P. Corporate social responsibility and firm performance in the hotel industry. The mediating role of green human resource management and environmental outcomes. Journal of Business Research 2021, 123, 57-69.

77. Kusluvan, S., Kusluvan, Z., Ilhan, I., \& Buyruk, L. The human dimension: A review of human resources management issues in the tourism and hospitality industry. Cornell Hospitality Quarterly 2010, 51(2), 171-214.

78. Baum, T. Human resources in tourism: still waiting for change? A 2015 reprise. Tourism Management 2015, 50: $204-212$.

79. Deery, M., \& Jago, L. A framework for work-life balance practices: Addressing the needs of the tourism industry. Tourism and Hospitality Research 2009, 9(2), 97-108

80. Fortune 2020 list. Available online: https://fortune.com/worlds-best-workplaces/2020/hilton/; retreived May 2021.

81. Goh, E., Muskat, B., \& Tan, A. H. T. The nexus between sustainable practices in hotels and future Gen Y hospitality students' career path decisions. Journal of Teaching in Travel \& Tourism 2017, 17(4), 237-253.

82. Grolleau, G., Mzoughi, N., \& Pekovic, S. Green not (only) for profit: An empirical examination of the effect of environmental-related standards on employees' recruitment. Resource and Energy Economics 2012, 34(1), 74-92.

83. Walsh, C., \& Sulkowski, A. J. A greener company makes for happier employees more so than does a more valuable one: a regression analysis of employee satisfaction, perceived environmental performance and firm financial value. Interdisciplinary Environmental Review 2010, 11(4), 274-282.

84. Grubor, A., Berber, N., Aleksić, M., \& Bjekić, R. The influence of corporate social responsibility on organizational performance: A research in AP Vojvodina. Anali Ekonomskog fakulteta u Subotici 2020, (43), 3-13.

85. INE. Spanish hotel employees. Available online: https://www.ine.es/jaxi/Datos.htm?tpx=37124; retrieved June 2021.

86. Hosteltur. Ranking Hosteltur grandes cadenas hoteleras. Available https://www.hosteltur.com/139934 ranking-hosteltur-de-grandes-cadenas-hoteleras-2020.html; retrieved June 2021.

87. Instituto Tecnológico Hotelero-ITH. Available online: https://www.ithotelero.com/; retrieved June 2021. 